\title{
Study on the Transformation of Jingdezhen Ceramic Culture Management
}

\author{
Bingfeng Liu * \\ School of Business Administration, JingDeZhen Ceramic Institute, Jiangxi Province, China \\ txcf2000@163.com
}

\begin{abstract}
Since ancient times, accumulated rich ceramic culture with porcelain industry in Jingdezhen, known as the capital of porcelain. The Millennium kiln fire, like a Phoenix, the birth of a Jingdezhen Ceramic Culture Management is brilliant. Jingdezhen Ceramic Culture Management has a diversity of characteristics: there is a long history of porcelain, precious cultural relics, and the traditional porcelain technology, a large number of ceramic artists, rich ceramic products, and unique ceramic custom and so on. Jingdezhen Ceramic Culture Management is the outstanding representative of Chinese culture, the history of its transformation and practical thinking is the current more popular research direction. From four perspectives of economic and political, cultural, social and ecological aspects, this paper discusses the background of the transformation of Jingdezhen Ceramic Culture Management, and studies the practical value of the transformation of Jingdezhen Ceramic Culture Management.
\end{abstract}

Keywords: Jingdezhen, Jingdezhen Ceramic; Ceramic culture management, History and reality; Transformation.

\section{Introduction}

Throughout the history of the development of Chinese culture, we have seen many different concepts, different creative thinking and cognitive conflict and integration, innovation and development. This is the cultural development of real and practical process, but in different historical periods will emerge some representative, become the era of cultural symbols and cultural landmarks, to become the nation's memory and pride, in the development of national history forever. Jingdezhen Ceramic Culture Management is Chinese culture outstanding representative, along with the great changes in the world economy, social structure and Chinese culture, society, economy, art, politics, Jingdezhen Ceramic Culture Management and also in unceasing development and transformation. The development and transformation of Jingdezhen Ceramic Culture Management has given the new life to this cultural core [1]. Changes in the development and transformation of Jingdezhen Ceramic Culture Management continue to catalyze the Jingdezhen ceramic art development process, to find and establish a new system of value orientation, this is the era of giving the Jingdezhen Ceramic Culture Management of responsibility, as well as a driving ahead of Jingdezhen Ceramic Culture Management product market power [2].

The historical development of Jingdezhen Ceramic Culture Management and the transformation of reality to promote the value judgment to the economic, academic and cultural values of the three important considerations, this will form a rational value concept, spiritual consumption and cultural criticism of the awakening, as well as the development of Jingdezhen ceramic cultural and creative aspects of the important influence [3].

\section{Background Analysis on the Transformation of Jingdezhen Ceramic Culture Management}

\subsection{Background Analysis of Economic and Political}

Since 1990s, the world's political, economic and social patterns have changed dramatically, and the world's multi polarization process has been moving forward. Globalization in breaking down the boundaries at the same time also to break the control of ideology, touched the conflict and reconstruction of social value and social cognition. To this end, the multi polarization and the change 
of the world pattern in the era of globalization is reflected in the cultural value [4]. Many Western value began to penetrate into all aspects of Chinese culture, the Chinese nation in the recognition of the importance of cultural identity, efforts to strengthen the culture of self-recognition and reconstruction, as a typical representative of the culture of the Chinese nation Jingdezhen Ceramic Culture Management development and transformation is China's cultural identity.

\subsection{Cultural Background.}

From the perspective of the development of the world's cultural field, the emergence of the world's ideological and cultural staggered development, the new trend of continuous integration. Values of different culture, ideology comes on stage in succession, all kinds of social thoughts, mental strength interwoven with agitation, this to promote the interaction of different national ideology, culture, learning and learning to promote the dissemination of advanced culture value concept has an important role. After the eighties of the 20th century, the historical development of Jingdezhen Ceramic Culture Management experienced spiritual and cultural reconstruction, to cultivate and carry forward the three different stages, from the development of marginalized and into the mainstream culture, especially in today, Jingdezhen Ceramic Culture Management has become the important strategy of the development of cultural and creative industries [5]. This performance, on the one hand, Jingdezhen Ceramic Culture Management to help people to lay the taste and accomplishment, the formation of a new concept of life values, played the role of enlightenment and nurture. On the other hand, Jingdezhen Ceramic Culture Management has had a profound cultural background and accumulation, with the spirit of creativity and self-transcendence, as the representative and soul of Chinese culture. At the same time, Jingdezhen Ceramic Culture Management has been developed and transformation become the real economy, especially the rapid development of Jingdezhen ceramic creative culture industry to drive the upgrading of traditional industries, enhance the strength of regional economy plays the vital role.

\subsection{Social Background}

After the 90 "s of the 20th century, the market economy began in all aspects of the impact on social life, physical force become factors important in people's lives, changed the structure of traditional ideas in social system, morality becomes vague and loose. The value orientation of some traditional culture begins to drift and transform, and the society under the authority of ideology becomes a non-ideological society [6]. At the same time, many Western value theory and the idea of the invasion the body of the traditional culture, has a profound impact on many Chinese cultural consciousness; new social and cultural forces quietly grows and the traditional culture, the old rules orderly exit and intertwine. The relationship between culture and economy, culture and society, culture and life is undergoing profound changes. Traditional Jingdezhen Ceramic Culture Management has moved from pure artifacts to a diversified pattern, and become one of the representatives of the new cultural and creative.

\subsection{Ecological Background}

Ecology is the principle of survival of the fittest, natural selection; therefore, the formation of cultural virtuous circle is the cultural system development inevitable requirement. The elements of Jingdezhen Ceramic Culture Management is some ecological unit or branch of the ecological environment, to keep dynamic equilibrium and stable development of the the ecological factors, the ecological environment of culture effectively cultivate and maintain. The development of Jingdezhen Ceramic Culture Management experienced in the Song Dynasty, the 20th century in the mid-1990s, 2005-2006 three peaks, especially the song of Jingdezhen Ceramic attention, laid the historical and ecological foundation for the Jingdezhen Ceramic Culture Management. In 2005-2006 Jingdezhen Ceramic Culture Management with artwork market development appeared in the development of the excellent situation. But due to the market - oriented than material, the aesthetic characteristics of the culture was shaken, commercialization, speculation, utilitarian tendency is obvious, Jingdezhen Ceramic Culture Management appeared some is not conducive to the long-term development of ecological phenomena, such as speculation, expansion of the material, such as. The distortion of the price and value of the ceramic art market has influenced the ecological structure of Jingdezhen 
Ceramic Culture Management, which has destroyed the ecological balance of Jingdezhen Ceramic Culture Management. Based on this situation, the transformation of Jingdezhen Ceramic Culture Management is actually the process of adjustment and reconstruction, Jingdezhen Ceramic Culture Management to build through the transformation of the ecological environment of excellent cultural.

\section{The Practical Value of the Transformation of Jingdezhen Ceramic Culture Management}

The development of Chinese culture has entered the cultural consumption and the transformation of Jingdezhen Ceramic Culture Management not only from non-primitive abstract scientific world regression and transcendence to primitive life world, but also changes in the catalytic Jingdezhen Ceramic Culture Management development. In this change, looking for and found that the support of the times to give Jingdezhen ceramic cultural historical responsibility, but also the real choice of Jingdezhen ceramic cultural products market.

\subsection{Construct a New System of Cultural Value in the Inheritance}

Jingdezhen Ceramic Culture Management is concerned, its cultural heritage is essentially the traditional culture of Jingdezhen Ceramic Culture Management of excellent cultural spirit and humanistic concern of the philosophy of inheritance. No inheritance of Jingdezhen traditional ceramic culture, there is no modern Jingdezhen Ceramic Culture Management of the survival of the soil, this is the Jingdezhen Ceramic Culture Management to become one of the excellent culture of the Chinese nation on behalf of magic, as well as the spirit of Jingdezhen lies. The inheritance of traditional culture is the responsibility of the contemporary ceramic art workers, and constantly on the basis of inheritance and innovation. Therefore, perseverance to watch traditional Jingdezhen Ceramic Culture Management, the guardian of the cultural and spiritual home is the inevitable requirement of reconstructing the cultural value system, in the traditional Jingdezhen Ceramic Culture Management watch and the succession of ceramic art workers is leading the Jingdezhen Ceramic Culture Management products market leader.

\subsection{Explore the New Cultural Value System in the Combination of Painting, Modeling and Ink Painting}

The sketch is about modeling portraits, is a kind of painting skills, is to grasp the object depicted the soul. Modeling and ink painting is different, in addition to the shape of the text, but also concerned about the characteristics of objects, to the characteristics of the objects and the core of the unique form of display. Therefore, the sketch can improve the level of modeling, modeling emphasizes in the "like and not like" to find a balance between. Pen and ink work is able to give the sketch and shape to the subjective emotion, to express the artist's personal understanding of ceramic art. The wonderful combination between the three can improve the spiritual realm of Jingdezhen Ceramic Culture Management and art.

\subsection{Discover the New Cultural Value System in the Exploration of the Academic School}

The school's cultural and artistic exploration is the main art school of Chinese art exploration, and its main body is related to the University teachers. Because these teachers engaged in Jingdezhen Ceramic Arts and culture related work, its relatively independent, with characteristics of the personal freedom, creativity, attention to the specification of the themes, techniques and artistic language, the rejection Mei secular culture tendency, pay attention to the rational and cognitive. On the traditional basic skills training more attention, avoid the social and cultural trends. Therefore, the transformation of Jingdezhen Ceramic Culture Management of the new cultural value system can be found in the Institute of exploration of its support.

\subsection{Against Copy Tracing, Kitsch Reconstructs the New Cultural Value System}

Jingdezhen Ceramic Culture Management is a typical representative of the traditional culture, since the Song Dynasty, the art and culture development always uphold the ancient skills, pay attention to the original and thought; many of the Jingdezhen ceramics culture art creator has still the road silently exploration. But blindly copy tracing easily from the cultural status quo, ignoring the cultural creativity and innovation and personalized performance, makes the artistic form of Jingdezhen 
Ceramic Culture Management become more rigid, Jingdezhen Ceramic Culture Management eventually stalled. On the other hand, by the impact of market economy and Western cultural values, Jingdezhen Ceramic Culture Management values be commercialized consciousness infestation hype, Mei vulgar phenomenon is more serious, the rationality of traditional Jingdezhen Ceramic Culture Management and aesthetic lost profundity; some cultural workers over the pursuit of skill, style and visual, for the lack of the content of the innovation value judgment. Therefore, against the copy tracing and tendency of vulgarization is the establishment of Jingdezhen Ceramic Culture Management of the new value system is the inevitable choice.

\section{Market Thinking in the Transformation of Jingdezhen Ceramic Culture Management}

Jingdezhen Ceramic Culture Management transformation process is the traditional Jingdezhen Ceramic Culture Management to modern Jingdezhen Ceramic Culture Management conversion process, this process brought idea, ecology, the values of many changes, Jingdezhen Ceramic Culture Management after the Millennium toward the benign development of higher level. Among them, the most closely related to the transformation of the real market is deeply affected by the. In Jingdezhen ceramic cultural products market to enter the adjustment today, pay close attention to the rational regression of Jingdezhen Ceramic Culture Management, and promote the reasonable transformation and regeneration of Jingdezhen Ceramic Culture Management is the most realistic thinking direction. 4.1 The Change of the Value Judgment of Jingdezhen Ceramic Culture Management

Whether art or other cultural products, the value of many investment institutions, collectors, and consumers have had a new change. On the one hand, the market price is no longer the only criterion, works, works of art or other cultural products of academic, economic, social, artistic value is the key, to experience the test of time and market products is really valuable. On the other hand, the turnover of many products do not necessarily high price to ensure quality to raise prices, the number is not the more the better; in works of art, works of value judgments, the personality characteristics of Jingdezhen Ceramic Culture Management products is more important.

\subsection{The Evolution of Jingdezhen Ceramic Cultural Value Investment}

At present, Jingdezhen Ceramic Culture Management products of investors has from the original pure conformity, blind mentality change over, more emphasis on the brand and creative innovation value, use more energy to analyze the culture of Jingdezhen ceramic product quality. Jingdezhen Ceramic Culture Management value investment gradually tend to invest to the high brand value and good market reputation of the products, good find intrinsic quality excellent, long-term growth, huge potential investment target, by way of long-term holders, repeated investment, equity incentives to share value of Jingdezhen ceramic cultural market.

\subsection{Consumption Transformation of Jingdezhen Ceramic Culture Management Market}

Jingdezhen Ceramic Culture Management transformation has brought the fundamental change of the concept and aesthetic sentiment of Jingdezhen Ceramic Arts and culture, ceramic art aesthetic the former superior highbrow art and literature has gradually penetrated into people's lives, became the contemporary aesthetic fashion a more prominent cultural landscape. Along with the gradual improvement of people's consumption level, people's way of life happened great changes gradually from quantity to quality, from simple food and clothing to enjoyment, so to Jingdezhen Ceramic Culture Management product consumption were re defined. People are paying more attention to the spiritual consumption, from the psychological pay more attention to enjoy, Jingdezhen Ceramic Culture Management products break through the bondage of traditional cultural artifacts, integration of the people's demand of beauty and life, for people to bring spiritual consumption transformation.

\section{Summary}

Creative innovation is the key to the development of Jingdezhen ceramic cultural market, only constant innovation is the ultimate source of Jingdezhen Ceramic Culture Management to survive in the market. Jingdezhen Ceramic Culture Management, the essence of this art form requires people to 
continue to pursue the perfect, the pursuit of creative innovation. In the process of exploration and innovation, through the cultivation of Jingdezhen Ceramic Culture Management and ecological environment by meticulous care of the market, through the creativity of art workers play, Jingdezhen ceramics industry will radiate new vitality. Current Jingdezhen Ceramic Culture Management market is the lack of creative and innovative products, the lack of a diversified way of thinking and ideas, convergence is stronger, the price is difficult to distinguish, multi-level products less. Therefore, constantly creative innovation is the era of Jingdezhen ceramic cultural market to give the biggest harvest.

Today, we stand at the intersection of Jingdezhen Ceramic Culture Management transformation of history and reality, with a comprehensive view on the context of the development of Jingdezhen ceramics culture and style, which is the outstanding cultural exploration a move on the road.

\section{References}

[1] Xi Mu. An Introduction to Chinese Art Capital Market [M], China Bookstore Press, 2010.(In Chinese)

[2] Hu Juan. The Protection and Transmission of the Cultural Heritage of Jingdezhen Ceramic. Chinese Ceramics, Vol.48 (2012) No.10, pp: 34-36. (In Chinese)

[3] Zhang Bianling. The Historical Changes of Porcelain Art in Jingdezhen. LAN Tai World, (2012) No.7, pp: 85-86. (In Chinese)

[4] Paul Romer. Increasing Returns and Long-run Growth. Journal of Political Economy, (1986)No.94, pp:122-130.

[5] Throsby. Cultural Capital. Journal of Cultural Economics, Vol.23 (1999), pp:3-12.

[6] Richard Florida. The Rise of the Creative Class: And How Its Transforming Work, Leisure, Community and Everyday Life. Perseus Books Group, 2002. 